\title{
Households Headed by Women: Income, Employment and Household Organization
}

\author{
Shahnaz Kazi and Bilquees Raza*
}

\section{INTRODUCTION}

The poverty of households headed by women has emerged as an important development issue in the recent past. Evidence from many developing countries, specially in Latin America and Africa, has underlined the economic vulnerability of this group and predicted an increasing incidence of female-headed households in developing societies [Buvinic and Youssef (1978); Kossaudji and Mueller (1983); Merrick and Schmink (1983)]. Among Asian countries sample surveys have revealed a significant proportion of female-headed households in Sri Lanka, Malaysia and some states in India (Visaria 1980).

In the context of Pakistan, research in this area is virtually non-existent. Although the questionnaires of the various censuses do provide information on sex and other characteristics of household heads, this data are not available in tabulated form in any of the census reports. However, a recent survey of 1000 women in Karachi conducted in 1987 makes it possible for the first time to investigate, in detail, the characteristics of female-headed households. The sample of 680 working women and 320 non-working women covered a whole range of social and income classes. Among the 680 working women was included the sub-sample of 100 female heads of households. Combined information was collected on women and their households through a fairly lengthy questionnaire: the interview schedule comprised questions on earnings, ethnic affiliations, education, age, sex, and occupation of all household members, division of domestic responsibilities in the household and employment history of individual women.

This sample of 680 working women will be used to analyse the economic situation of households headed by women relative to households headed by men. The paper will compare income levels, household size and composition and employment patterns in the two sets of households. Further, the study will also investigate differences in income and employment options within the subset of households

*The authors are Senior Research Economist and Staff Economist respectively, at the Pakistan Institute of Development Economics, Islamabad. 


\section{DEFINITION OF FEMALE HEADSHIP}

Female-headed households are defined as households where women are the sole wage earners. These households could be further identified as de jure or de facto depending on whether the male partner is temporarily away or unemployed (de facto) or whether there is no permanent male head (de jure). The former category includes households where the male head is absent due to migration or is present in the house but does not contribute to the economic resources of the household due to illness/disability or unemployment. De jure female heads are permanently without male partners due to divorce, separation or widowhood. Among the 37 de facto female-headed households, 13 comprised of households headed by wives of migrants while the remaining 24 female heads were women whose husbands were not employed due to lack of jobs or because of ill health or old age Widows and divorcees constituted the majority of female household heads comprising nearly two-thirds of the sample.

The tendency of these women to support themselves reflects the combined influence of male outmigration and the break up of the extended family system. Large-scale outmigration of Pakistani workers to the Middle East had assumed tremendous proportions since the late Seventies with repercussions at the macro level on the economy as well as on the micro level on family structure. ${ }^{1}$ Among the migrants in the sample, the majority were working in the Middle East and included mainly production workers as well as a considerable proportion of pro fessionals and clerical workers. Of the total migrant families in the sample, 72 percent were living in female-headed households mostly in nuclear units.

Among the widows and divorcees in the sample, nearly 50 percent of the widows and 60 percent of the divorcees were fending for themselves. The fact that the majority of these women had to assume sole economic responsibility for their households indicates the weakening of the traditional kinship-based system of providing economic support to the women. The erosion of the extended family system has been attributed to poverty which makes it very difficult for families to continue providing financial assistance to female relatives. Findings of this survey for all working women, also, indicated a higher incidence of nuclear units among households of respondents in low-income occupations but the highest proportion of nuclear families ( 75 percent) were found among female-headed households. Households headed by males were much less likely to be nuclear ( 58 percent).

'For detailed analysis of the effects of migration on family structure [see Bilquees and Hamid (1981), Shaheed (1981) and Abbasi and Irfan (1983)].

\section{INCOME OF MALE AND FEMALE-HEADED HOUSEHOLDS}

The findings from Pakistani data further corroborate the evidence from a number of other less developed countries that households headed by women are found in the poorest strata of society. Nearly 63 percent of households headed by females fall in the lowest family income group of less than Rs 1000 per month as compared to only 7 percent of male-headed households in this group. Further, mean monthly household income for households headed by females was Rs 1192 less than one third the mean family income for male-headed households of Rs 4022 and slightly more than half the monthly earnings of the male head at an average of Rs 2079. Differences between earnings of respondents in the two subsets of households were less marked. Mean monthly income of female respondents in our survey living in male-headed households was Rs 1252 as compared to an average monthly income of women respondents who were heads of households of Rs 1024

However, household size was also considerably smaller on average in households headed by women comprising of 4.7 persons as compared to a mean of 6.6 persons in households with male headship. To adjust for these differences in household size, household income was also estimated on a per capita basis. The results indicate that the position of male-headed households is still considerably better with a per capita household income of Rs 771 a month as compared to Rs 435 for households headed by females.

The low economic status of households headed by women is the result of both demographic and economic factors. Although their average household size is smaller, the dependency burden, as measured by the non-earners to earners ratio and the children to adults ratio, is much higher among households headed by women than by men. Thus, the non-earners to earners ratio in female-headed households of 3.3 is more then double the corresponding figure of 1.6 for households headed by men. The differences in child-adult ratios, al though less marked, still indicate a considerably higher dependency burden for households headed by women as compared to male-headed households.

In economic terms the explanation of the high incidence of poverty in female headed households lies simply in the lower earning capacity of female heads of households. The main source of income in female-headed households are the head's earnings which, on average, comprise 92 percent of total family income. Thus, the occupation and income level of the female head of household determines the level of living of the household.

The women in question are not in any way prepared for their role as the sole economic providers for the family but are forced by circumstances to support themselves. Thus, more than three-fourths of the female-headed households had to take up employment due to a sudden deterioration in their economic situation 
caused by death or illness in the family or subsequent to a separation or divorce. These women entered the labour market after marriage and usually after the birth of at least one child. In fact, the majority take up employment after the birth of at least three children. The average age at starting work was 28.3 years amongst female heads as compared to 25.1 years for respondents in male-headed households. This employment pattern, shown to be characteristic of most low-income working women (Kazi and Sathar 1986), is even more pronounced in the case of female heads of households.

These women have little or no education and know only skills related to the household sphere. Their education and training characteristics limit their employment opportunities to low paying, menial jobs. As a result, female heads are overrepresented in the lowest occupation groups. Thus, 86 percent of the working women who were female heads were employed as factory workers, informal sector workers and home workers as compared to 66 percent of working women in these jobs among the sub-sample of male-headed households. Further, only 5 percent of professional women and 4 percent of the school teachers in the sample of working women lived in female-headed households as compared to more than one-third of the factory workers and nearly one third of informal sector workers.

\section{INCOME DIFFERENCES WITHIN FEMALE-HEADED HOUSEHOLDS}

Thus far, the discussion has focused on income differences between male- and female-headed households. However, the variations within the subgroup of households headed by females are also quite marked. The circumstances that lead to assumption of headship by females have very important implications for the economic conditions of these households. Hence, households headed by migrants wives and those headed by women with non-earning husbands represent two ends of socio-economic status within female-headed households. The former group has a mean household income of Rs 1851 which is nearly double the income of the latter group. The position of widows and divorcees is slightly better although closer to the bottom end of the scale at a household income of Rs 1084 and Rs 1173 respectively. In terms of household income per capita, households with non-earning husbands are shown to be even more severely disadvantaged with a per capita income of Rs 177 as compared to Rs 940 for the households run by migrants wives.

Differences in income levels within housholds headed by women, also, largely reflect variations in dependency burdens and in the earning capacity of the respondents. Among female-headed households the dependency burden is highest for the poorest group of households headed by wives of non-earning husbands and lowest for the richest households headed by migrants wives. The non-earners to earners ratio of the former group at 4.6 is nearly double the corresponding figure of 2.4 for the latter group.

Further, within the subset of female-headed households, the proportion of women in low-income employment was specially high among the subgroups of widows and wives of non-earning husbands at 100 and 91 percent respectively. At the other end of the scale, more than half the group of migrants' wives were employed in professional and semi-professional jobs. However, as mentioned earlier, this category among female heads belonged to a distinctly higher socio-economic level. They were much better educated, entered the labour force early and had a greater career orientation. Differences in the work options and employment patterns among the subgroup of women heads of households were reflected in differences in their monthly earnings. Average monthly income was highest in case of migrants' wives at Rs 1852 and lowest at Rs 664 for wives of non-earning husbands.

Thus, the earning capacity of women household heads was not only an important determinant of differences in economic status between female- and maleheaded households but alse of differences in income levels within female-headed households.

\section{HOUSEHOLD ORGANIZATION AND DOMESTIC DUTIES}

The burden of domestic duties was not very different for respondents from the two sets of households. Thus nearly 42 percent of the respondents in femaleheaded households and male-headed households bear the double burden of housework and paid employment. Across both sets of households their share of domestic tasks is primarily determined by the presence of other adult females in the households.

Since the economic survival of the household depends on the earnings of the female head, domestic obligations have to receive lower priority to the demands of earning a living. In most cases the conflict between domestic work and outside employment was resolved by putting female children to work in the house.

The daughter's role was specially important in the case of female-headed households due to the lower levels of income and the higher incidence of nuclear units in this subgroup. In the absence of other female relatives or hired help, young daughters in the family were often taken out of school to attend to domestic chores while the mother worked.

The idea of living in an extended family was viewed positively by the majority of working women but the preference was specially strong among women in lowincome occupations in both male- and female-headed households. Although joint families may lead to less autonomy for women in decision-making in the households, however, at very low levels of living economic and non-economic support provided by relatives seems to be valued more highly by the respondents. In this 
context it was interesting to note that among the migrants' wives, the most affluent group among women-headed households, there was a greater tendency to prefer the nuclear family while the preference for the joint family was strongest in case of women with non-earning husbands, the most economically vulnerable among the group of female-heads of households.

\section{CONCLUSIONS}

The paper was a preliminary attempt to describe the social and economic conditions of households headed by women. The analysis was based on a very small and, also, a purposively selected sample which may lead to some bias in our results, and, therefore, any conclusions that emerge can, at best, be tentative.

The findings indicate that the subset of female heads of households comprises of three distinct groups; wives of migrants, divorcees and widows, and wives of non-earning husbands. While the first group was relatively well-off and employed in white collar jobs, the other two categories - widows and divorcees and wives of non-earning husbands - did, indeed, belong to the poorest strata of society.

Their poverty stemmed partly from a high dependency burden but largely reflected the disadvantaged position of women in the labour market with the exception of a small group of highly educated women. Women heads of households have no prior commitment to their work role and are pushed into the labour market due to unfortunate circumstances. They are uneducated and the only skills they know are related to housework which are worth very meagre wages. Consequently, female heads of households tend to be disproportionately represented in the lowest level jobs.

Further, the findings of the study also indicated that female-headed households were more likely than male-headed households to have daughters take over housework from their mothers usually at the cost of their education. A tendency which would have serious repercussions on the education and earning capacity of the future generation of women in these households confining them to a vicious circle of low level earning activities.

The incidence of households headed by women is very likely to grow in Pakistan since the factors that lead to their emergence, i.e. migration and the break-up of the joint family, are associated with social change and development. Hence, further research is necessary to identify the specific needs of this expanding subset of the urban poor in terms of training, wages and conditions of work, job placement services, day, care facilities and other urban services. These are some of the areas which need to be addressed by planners and policy-makers to combat the multiple problems of this group.

\section{REFERENCES}

Abbasi, Nasreen, and Mohammad Irfan (1983). "Socio-economic Effects of International Migration on the Families Left Behind". Islamabad: Pakistan Institute of Development Economics. (PLM Project Report No. 7)

Bilquees, Faiz, and Shahnaz Hamid (1981). "Impact of International Migration on Women and Children Left Behind: A Case Study of a Punjabi Village”. Islamabad: Pakistan Institute of Development Economics. (Research Reports Series, No. 115)

Buvinic, Mayra, and Nadia H. Youssef (1978). "Women Headed Households: The Ignored Factor in Development Planning". Report Submitted to the Office of Women in Development, Agency for International Development, Washington, D.C.

Kazi, Shahnaz, and Zeba Sathar (1986). "Productive and Reproductive Choices: Report of a Pilot Survey of Urban Working Women in Karachi". Pakistan Development Review. Vol. XXV, No. 4.

Kossoudji, Sherrie, and Eva Mueller (1983). "The Economic and Demographic Status of Female Headed Households in Rural Botswana". Economic Development and Cultural Change. Vol. 31, No. 4.

Shaheed, Fareeda (1981). "Effects of Migration on Women in the Villages of Provenance”. Geneva: ILO. (Working Paper)

Thomas, Merrick, and Marrianne Schmink (1983). "Households Headed by Women and Urban Poverty in Brazil". In Mayra Buvinic et al. (eds.), Women and Poverty in the Third World. Baltimore: The Johns Hopkins University Press.

Visaria, Pravin (1980). "Poverty and Living Standards in Asia". Population Development Review. Vol. 6. 


\section{Comments on}

"Households Headed by Women: Income, Employment and Household Organization"

The paper is a useful addition to research material in an area in which very little Pakistan-specific data exists. It explodes a few myths, about a problem that is considered to be a non-issue by most people and Census Reports. It confirms some assumptions but also has a few grey areas.

The number of female heads of households is considered negligible here, as all women who are divorced or widowed are absorbed in to the extended family structure, thus coming under the protection of another male relative, who assumes the role of family head. Even where women assume total economic responsibility, or when men are absent for long periods of time, the man continues to be considered the head of household.

The research is limited to one city and the sample is small, so it cannot be considered nationally representative. However, in the perspective of large cities it gains credibility, in terms of what it establishes with supporting data and what it indicates through inference. It highlights that: women are increasingly becoming economically active as regular wage earners; female-headed households exist here and economic pressures are undermining family support systems. A common reason for entry into wage labour was a sudden deterioration in the economic situation.

The female households heads ratio of 1 out of 7 in the sample, seems insignificant as compared to the total female work force, but it identifies a hitherto un recognized fact. Indications are that the number of female-headed households is likely to grow, given the prospective increase in urbanization and its related problems.

Women, especially those from lower socio-economic backgrounds, are generally disadvantaged in terms of development options and economic productivity skills This holds true in comparison to both - men of similar socio-economic backgrounds, and women of better economic backgrounds. Within the sample, the proportion of women in low-income employment is specially high among widows and wives of non earning husbands, whose low educational/skill levels limit work options/earning capacity, and they were working out of necessity rather than choice.

One reason that a majority of female-headed households had smaller family sizes and tended to be nuclear can be that, in a household which has more than one unit, with male and female members supporting different units, the male earner will automatically be considered the household head, even if the woman's wage is equal or higher. Society does not conceive of women as economic providers so unless there is no other alternative, it is not considered appropriate for dependant relatives to live with women.

Information which would have helped to obtain a clearer perspective of the geographical, social and economic distribution of the sample in Karachi, can only be obtained by going back to the 1987 survey mentioned in the Introduction. Even so, some questions remain unanswered. There is no table establishing linkages between educational qualifications and occupations. The table on occupations contains some broad categories which need further definition, e.g., lower level professionals, informal sector and home workers. Where the husband is a migrant it is not clear whether he is contributing to the family income or not. If he is how can the wife be the sole wage earner?

The dependency ratio in terms of nonearning members was found to be higher in the female-headed households. The research did not cover a comparison in spending patterns which could have given a further indication of the quality of life in female-headed households. This could be a future area for research.

The research confirms that women's involvement in gainful employment does not lessen their domestic responsibilities, unless their income is enough to afford servants, or these responsibilities can be passed on to other female family members. Especially in case of nuclear female-headed households this negatively affects the elder daughter who takes over the housework at the cost of education. There is no indication about the impact on the education of male children or their age of entry into the labour market.

The definition did not mention marital status as a consideration for inclusion in the sample. So it seems strange that there are no single women in the sample, either among the female household heads or as part of male-headed households, since it is generally considered that women work when they are single and stop working after marriage.

The findings imply "repercussions on the education and earning capacity of the future generations of women in these households". These repercussions are imminent not only for these households. The majority of our women are ill prepared to effectively support themselves and their families should the need arise. A follow up of this research could be a more detailed elaboration about the possible impact of womens' economic dependency on the nation's overall development and the quality of life of future generations of men and women.

Apart from the paper's recommendation for further research in urban areas, other requirements are - linking these findings to existing research on related issues, 
